\title{
Microbial stabilization of Plutonium in the Subsurface Environment
}

\author{
B. D. Honeyman ${ }^{1}$, A. J. Francis ${ }^{2}$, C. J. Dodge ${ }^{2}$, J.B. Gillow ${ }^{2}$ and P. H. Santschi ${ }^{3}$
}

${ }^{1}$ Environmental Science and Engineering Division, Laboratory for Applied and Environmental Radiochemistry, Colorado School of Mines, Golden, CO 80401; 'Environmental Sciences Department, Brookhaven National Laboratory, Upton NY 11973; ' ${ }^{3}$ epartment of Oceanography, Texas A\&M University at Galveston, Galveston, TX 77551

\section{Overview.}

This report outlines the results of work performed at the Colorado School of Mines, Brookhaven National Laboratory and Texas A\&M University during the second reporting phase of this project (approximately 2.5 years of project duration).

The sub-projects focused on this year include:

A. Biotransformation of Pu-contaminated soil

B. Environmental colloids at the Rocky Flats Environmental Technology Site

C. Production, isolation and characterization of EPS (exopolymeric substances, or: exopolysaccharides.

D. Colloid trapping'

E. Determination of stability constants of complexes of Pu(IV) with organic ligands.

F. The role of bacterial EPS in the transport of Pu through saturated porous media.

\section{Details of Individual sub-Projects.}

Our current NABIR project included elements on: isoelectric focusing experiments to determine the oxidation state, molecular weight, and association of $\mathrm{Pu}$ with organic and mineral matter from contaminated soils in Colorado; the isolation, separation, purification and characterization of polysaccharide-rich EPS from bacteria cultures for use in biotransformation and complexation experiments; evaluation of Pu complex formation with environmentally relovant organic ligands, ineluding bacterial exudates and the development of methods for determining the stability constants for Pu with polyprotic ligands; the biotransformation of $\mathrm{Pu}$ in contaminated soils; $\mathrm{Pu}$ oxidation state determination; and $\mathrm{Pu} /$ citrate biodegradation. Highlights are summarized below; some results are presented in the annual NABIR reports for this project.

Current results progressed as follows: Microbial transformation of RFETS soil $\rightarrow$ Isolation of the predominant colloidal Pu(IV) species in RFETS soil $\rightarrow$ Isolation of EPS from NABIRrelevant microorganisms $\rightarrow$ Interaction of Pu(IV)-EPS with minerals $\rightarrow$ Understanding the thermodynamic stability of Pu(IV) in assaciation with microbial ligands. These results lead us to focus the current proposal on gaining a detailed understanding of the biogeochemistry of $\mathrm{Pu}(\mathrm{IV})$ colloids (inorganic and organic) with emphasis on attenuation processes for these mobile phases.

2.1 Biotransformation of Pu in Contaminated Soil. Microbial activity can affect the stability and the mobility of Pu in soils and sediments over the long-term in the following ways: (i) dissolution due to production of organic acids and sequestering agents, ii) reductive dissolution of iron and release of Pu associated with iron oxides, (iii) immobilization due to precipitation 
reactions and by biomass/cellular polymeric substances and exopolymers, and (iv) biodegradation of the organic carbon associated with Pu fractions. We examined the influence of anaerobic microbial activity on $\mathrm{Pu}$ mobility in $\mathrm{Pu}$ contaminated soil from the Rocky Flats Environmental Technology Site (RFETS). Two soils from the $903 \mathrm{Pad}$ lip area, the source-term for the contaminated soils and ponds at RFETS, were used with total ${ }^{239,240} \mathrm{Pu}$ content of $246 \mathrm{pCi}$ $\mathrm{g}^{-1}$ (4 ppb Pu, soil sample 1 ) and $78 \mathrm{pCi} \mathrm{g}^{-1}$ (1 ppb Pu, soil sample 3). The sequential selective extraction protocol of Yong et al. (1993) was used with modification to obtain information regarding the mineralogical distribution of $\mathrm{Pu}$ in the soil sample. The majority (60\%) of the total $\mathrm{Pu}$ in the soil was found to reside in the inert fraction (HF and $\mathrm{HClO}_{4}$ digestion) of sample $\mathrm{I}$, while the majority $(80 \%)$ was found to reside in the organic fraction $\left(\mathrm{H}_{2} \mathrm{O}_{2} / \mathrm{NH}_{4} \mathrm{OAc}\right.$ digestion) of soil 3. In addition, $2.2 \%$ and $1.9 \%$ of the Pu resided in the Fe and Mn oxide fraction of sample 1 and 3 , respectively.

Five grams of the soil were prepared under anaerobic conditions in $125 \mathrm{ml}$ serum bottles, stoppered with thick butyl-rubber stoppers, with $75 \mathrm{ml}$ of the following amendments: i) prereduced (boiled and $\mathrm{N}_{2}$-purged), DI $\mathrm{H}_{2} \mathrm{O}$ (no-amendment); ii) pre-reduced DI $\mathrm{H}_{2} \mathrm{O}$ w/ $0.5 \%$ w/v glucose, $0.015 \% \mathrm{w} / \mathrm{v} \mathrm{NH}_{4} \mathrm{Cl}$, and iii) pre-reduced $\mathrm{DI} \mathrm{H}_{2} \mathrm{O}$ w/ $0.5 \%$ w/v sodium lactate, $0.015 \%$ w/v $\mathrm{NH}_{4} \mathrm{Cl}$. Supematant samples were monitored aver 45 days for $\mathrm{pH}, \mathrm{Fe}^{2+}$ and $\mathrm{Fe}^{3+}$, organic acids, and at 45 days ${ }^{239,240} \mathrm{Pu}$ in the unfiltered supematant was detemined by alpha spectroscopy.

Figure 2 shows the dissolution of iron from the two soils as a result of microbial activity after 45 days. Figure 3 shows the concentration of Pu detected in the unfiltered supernatant at the same time period. The glucose treatment mobilized $\mathrm{Pu}$ from Soil 1 to the greatest extent $(10 \mathrm{pCl}$ $\mathrm{g}^{-1}$ dry weight or $4.1 \%$ of the total activity) as well as iron; Pu in this soil resides in the inert fraction but may be accessible in the iron-oxide fraction. Soil 3 showed litule mobilization of Pu above that which was detected in the water treatment indicating that the Pu associated with the organic fraction may be more stable. Lactate had little effect on iron or Pu mobilization. These results show that fermentative microbial activity can mobilize Pu as Pu colloids in contaminated soil possibly due to dissolution of iron phases. The identity of the bacterially-mobilized Pu species is under investigation.

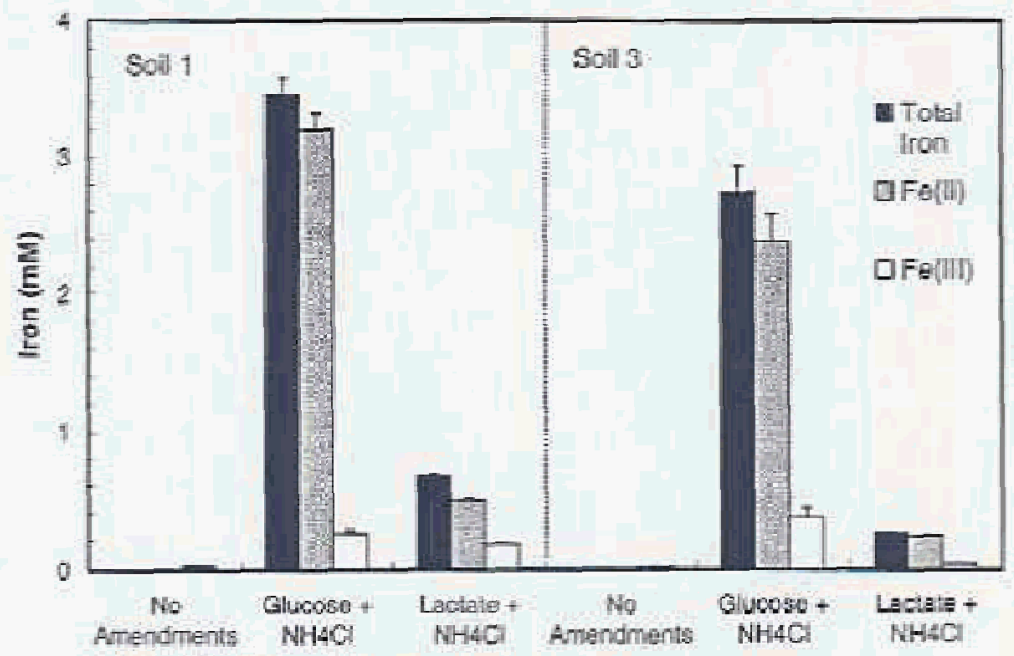

Figure 2. Dissolution of lica was greatest in Soll 1 incubated with glucose: lesser amounts of iron were dissolved from lactate amended samplos. 


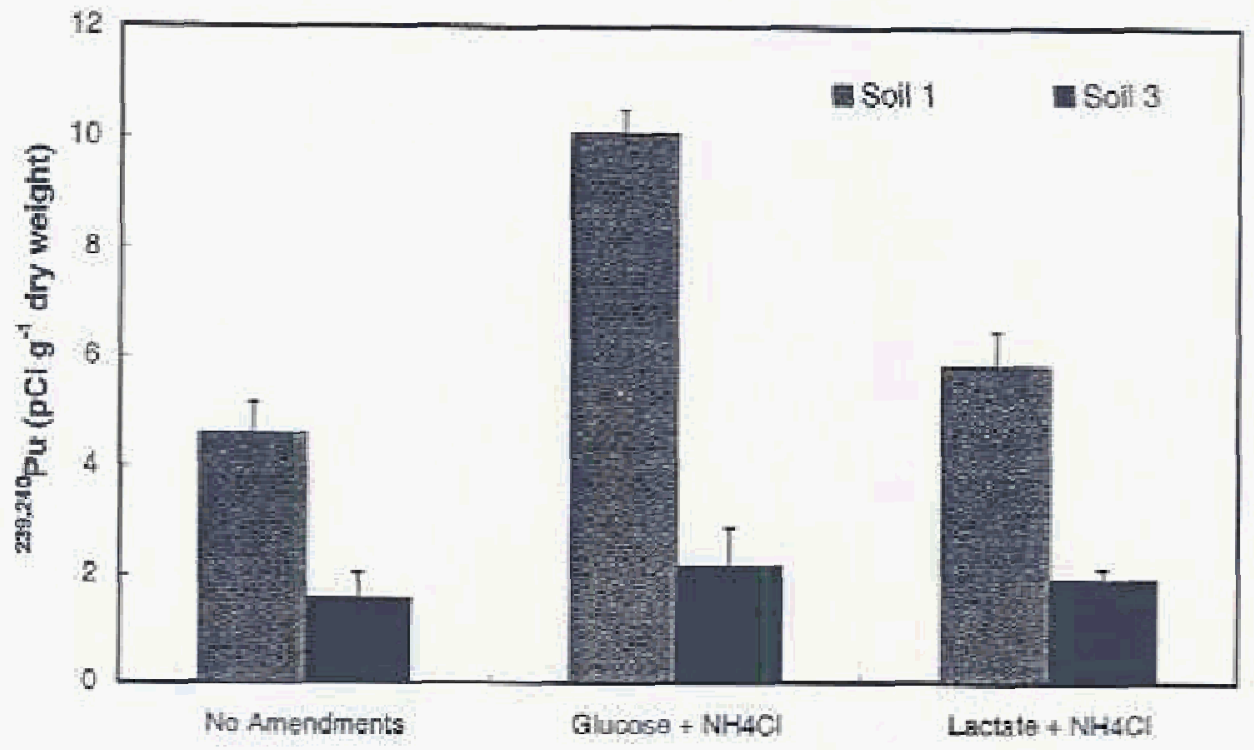

Figure 3. Pu was mobilized in the unfitered supematant of soll 1 atter 45 days with glucose amendment while less Pu was mobilized in soil 3.

2.2 Environmental colloids at the Rocky Flats Environmental Technology Site (RFETS): Santschi ot al. (2002 a,b) show that Pu mobility at the RFETS site is controlled by in the presence of iron-enriched humic acid or by acid polysaccharide colloids that had been identified in RFETS soils and surface waters. In this study, a Pu(TV) containing $10 \mathrm{kDa}$ organic-rich colloid with $\mathrm{pH}$ IEP of around 3 was separated from soils. Furthermore, TEM (transmission electron microscopy) and chemical analysis of surface groundwater colloids from the Rocky Flats soils demonstrated that there were two types of organic colloids in these groundwaters: larger semi-crystalline cellulose-type degradation products, and smaller humic-type aggregates (Roberts et al., 2004). Chemical analysis of these organic-rich colloids demonstrated substantial gradients of $\mathrm{Pu} / \mathrm{OC}$ and $\mathrm{Fe} / \mathrm{OC}$ ratios $(\mathrm{OC}=$ organic carbon) from surface waters to groundwaters at this site, suggesting a close coupling of the fate of $\mathrm{Pu}$ to that of organic carbon and iron in these environments. Phosphate was found to greatly diminish the mobility of total Pu and reduced particle residence times in holding ponds (Roberts and Santschi, 2004b).

2.3 Production, isolation and characterization of EPS (exopolymeric substances, or: exopolysaccharides): EPS were extracted from four bacteria species cultured in the lab: a) two aerobic soil bacteria: Pseudomonas fluorescens Biovar II and Pseudomonas florescens; b) one anacrobic bacterium, Clostridium sp. $\mathrm{BCl}$ and c) a facultative iron-reducer: Shewanella putrefaciens. After testing a number of different published extraction procedures the results of which strongly depend on the subsequent use and application of EPS, we eventually settled on a procedure that separates EPS that are in solution from those that initially stay attached through ultracentrifugation. Those in solution were further separated and purified through ethanol precipitation, addition of $\mathrm{NaCl}$ to help in the isolation process and the addition of proteinase to degrade protein compounds in the nutrient broth and bacterial EPS samples, as well as subsequent dialysis and lyophylization. The EPS from the particulate (capsular) fraction was separated through resuspension, ultracentrifugation, and ethanol precipitation in the presence of 
$\mathrm{NaCl}$ and subsequent dialysis and lyophylization. The final product was reprocessed, after initial filtration, through subsequent alcohol precipitation steps in a clean-room. Chemical purity of the different batches of each species and each fraction was verified through chemical analysis, which indicate that EPS-carbon consists $40-60 \%$ of total carbohydrates, $5-20 \%$ of proteins, $3-20 \%$ of uronic acids (which make up 10-30\% of total carbohydrates). Galacturonic acid was a principal constituent of the EPS, as shown by GC-MS analysis. Physical purity was verified through TEM analysis (Fig. 4). Each batch produced 5-10 mg of freeze-dried material. Further chemical characterization through GC-MS analyses is in progress.

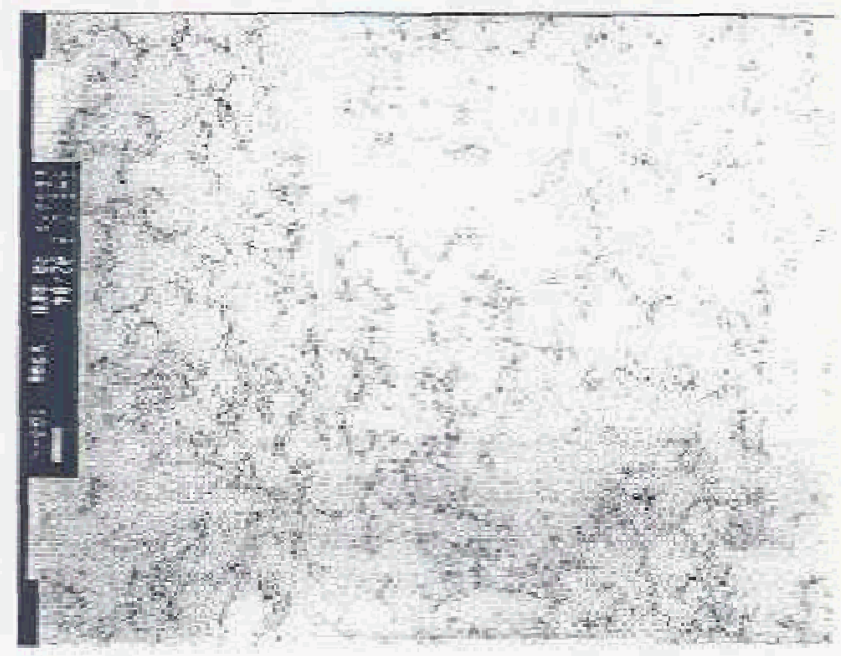

Fig. 4. TEM picture of dissolved EPS from Shewanella putrefaciens. Results from particulate fractions appear similar.

2.4 'Collold trapping: Preliminary experiments on Pu(TV) sorption to colloidal silica (with different pore size and surface area) in the presence or absence of model acid polysaccharides, as well as EPS harvested from soil bacteria (e.g., three aerobic soil bacteria: Shewanella putrefaciens CN32, Pseudomonas fhorescens Biovar II, and Pseudomonas florescens; and one anaerobic bacterium: Clostridium sp. BC1) suggest that microbially produced EPS can act as a colloid trap through a combination of steric, hydrophobic and hydrophilic interactions (Roberts et al., 2004c). Colloid trapping by mineral particles resulted in an enhancement of the $\mathrm{K}_{\mathrm{d}}$ value for Pu onto mineral particles such as silica (Santschi er al., 2004), as compared to the linear sum of the individual $K_{d}$ values (see Fig. 5).

2.5 Determination of stability constants of complexes of Pu(IV) with organic ligands. Here we focused on the complexation of Pu with the lipopolysaccharide (LPS) exocellular polymeric substances LPS-EPS component of natural organic matter. Much of EPS is composed of exopolysaccharides that are hydrophilic macromolecules consisting of monosaccharide units; as such, LPS-EPS are highly dispersed and complex molecules with a substantial polyfunctional, and polyelectroytic behavior (Stefansson, 1999; Seltmann and Holst, 2001). 

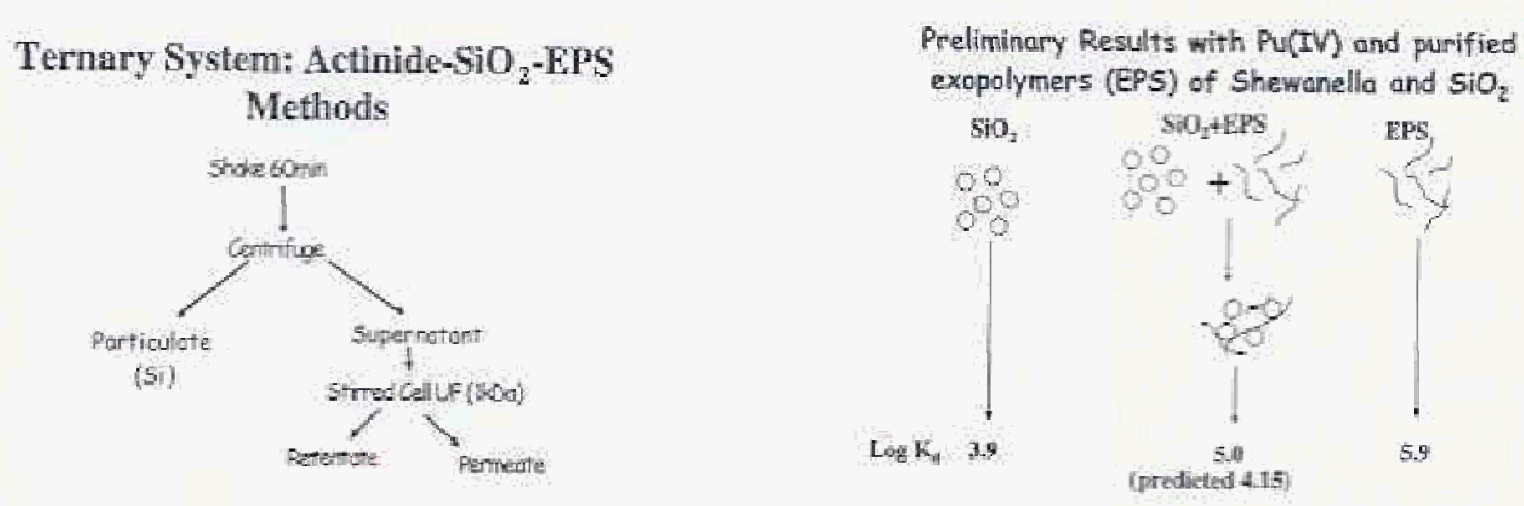

Fig. 5. a) Methodology (left) and b) preliminary results (right) from Pu(IV) sorption experiments in the ternary system: $\mathrm{Pu}(\mathrm{IV}), \mathrm{SiO}_{2}$, and $\mathrm{EPS}$, showing the enhancement effect in $\mathrm{K}_{\mathrm{d}}$ values as compared to predictions based on endmember values.

There are two common LPSEPS' $\mathrm{s}$; cellulose and starch, both of which are derived from plants (Murphy, 2000). Microorganisms can also produce LPS-EPS; it is located in the cell wall of bacteria or outside of the cell surface (Seltmann and Holst, 2001). Due to the strong tendency of acid polysaccharides for complexation with metals, LPS-EPS have been used for the removal of toxic metals from wastewater (Fukushima et al., 1999). Complexation of metal ions with polysaccharides is not fully understood but is believed to oecur through carboxylic groups (Fane et al, , 1992). The requirement for establishing and maintaining direct-contact between dissimilatory iron reducing bacteria and iron oxides, so that metal reductases can function effectively, is accomplished by LPS-EPS (Korenevsky et al., 2002).

$\mathrm{Pu} /$ organic ligand stability constants were determined through the application of a ligand competition method utilizing cation exchange resins. Details of the procedure can be found in Lenhart ef al. (2000). Stability constants have often been estimated using Schubert's method; Schubert's method is a linearization technique used to analyze ion-exchange data. Lenhart $e t$ al. (2000) provides a detailed explanation of Schubert method (Schubert, 1948). Schubert's method, however, has limited applicability. As a result, a new data evaluation method that utilizes FITEQL (Herbelin and Westall, 1996) is being developed by our research NABIR group to estimate stability constants for complex, polyprotic macromolecules. FITEQL is a computer program that can be used to determine "best-fit" equilibrium constants for reactions that are postulated to explain experimental data.

Stability constants for Pu binding with the following ligands have been determined thus far: citric acid (to validate the procedure), galacturonic and alginic acids, and EPS from the bacteria Clostridium sp., Psendomonas flworescens and Shewanella putrefaciens.

Galacturonic acid is a principle component ( $40-60 \%$ ) of pectin, a polysaccharide found in plants (Narkhede et al. 1994). Galacturonic acid has also been identified as part of this research as a predominant exudate ( $>1 \mathrm{kD})$ produced by Clostriditum sp. Alginic acid was used as a surrogate for the polysaccharide component of NOM. Alginic acids are a family of hydrophilic, colloidal polysaceharides commercially obtained from brown seaweeds (Stefansson, 1999). Bacterially-produced alginate is commonly present in soil environments due to production by $\mathrm{N}_{2}$-fixing bacteria of the genus Azotobacter and has been studied for its ability to stabilize biofilms and protect bacteria of the genus Pseudomonas from antimicrobial agents (Sabra et al., 
2000; Brown et al., 1995; Hamion et al., 2001). Alginate is an unbranched, binary copolymer composed of varying proportions of B-D mannuronic acid and $\square$-L-guluronic acid linked through the 1- and 4-positions. Mannuronic and guluronic were also identified as predominant components of Clostridia sp.

Proton binding to organic macromolecules is 'localized'. However, most descriptions of proton binding to natural organio ligands are based on macroscopic, delocalized binding constructs. Affinity distribution models (e.g., Westall et al., 1995) are centered on the idea that it is possible to describe the titration behavior of a complex molecule as a mixture of simple monoprotic acids or bases. The actual nature of the distributions derived from a titration curve can be quite varied (e.g., smooth or discrete) but generally the range of distributions provides good fits to the tiration data. Whatever the goodness of fit, however, the affinity distributions provide litule insight to the molecular-level mechanisms; however, they provide mathematical tractability for use in computer speciation codes.

Figure 6 shows the distributions of $\mathrm{pK}_{\mathrm{a}}$ values determined from inverse modeling of alginic acid Potentiometric titration data. In this scheme, $p K_{2}$ values are arbitrarily pickod (e.g., 2, 4, etc.) and the site specific concentrations (mmol g${ }^{-1}$ ) are inverse modeled. The ligands with $\mathrm{pK}_{2}$ values of 2 and 4 may be considered to be representing carboxylic acids.

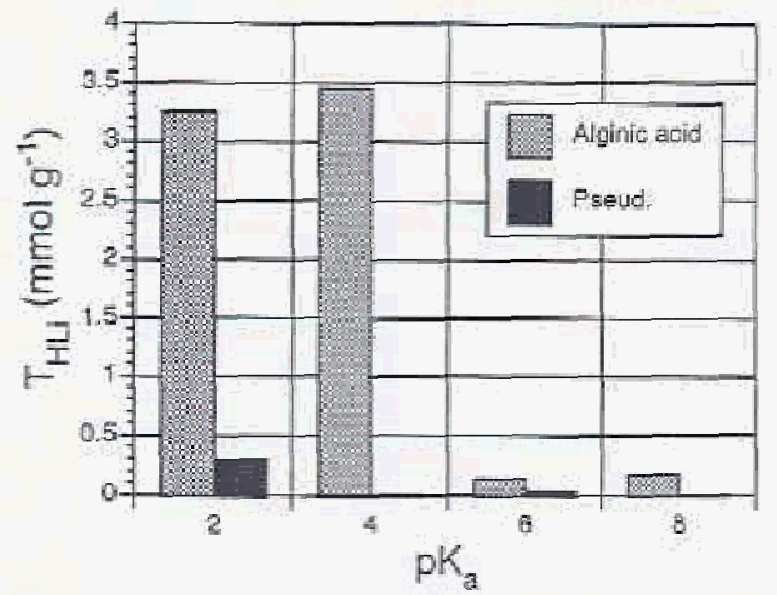

Figure 6. Graphical representation of the distribution of alginic acid and Psendomonas fworesicens EPS 'ligands' using the discrete ligand affinity distribution approach. Bacterially-produced alginate is commonly present in soil environments due to production by $\mathrm{N}_{2}$-fixing bacteria of the genus Azotobacter.

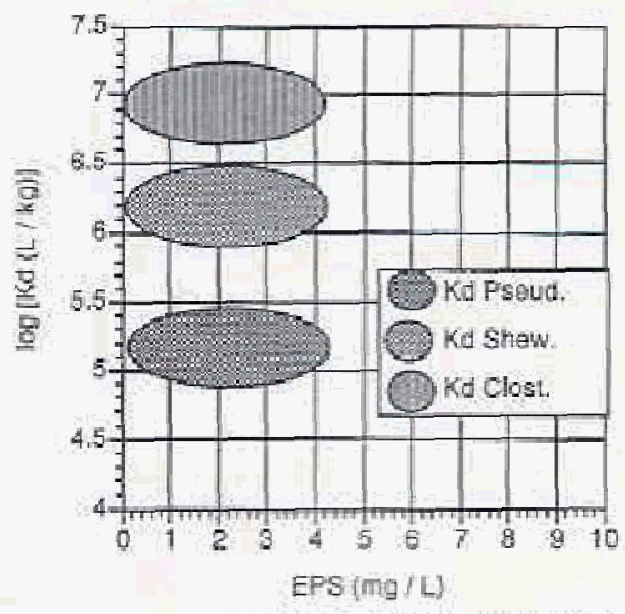

Figure 7. Comparison of Pu (IV) association with EPS from the target bacteria Clostridum sp, Psewdomonas fuorescens and Shewanella putrefaciens. Note: for comparison, the $\mathrm{K}_{d}$ for $\mathrm{Pu}$ binding to alginic acid is $-10^{5} \mathrm{~L} / \mathrm{kg}$. Because the Pseudomonas" has fewer acid groups, (per mass) relative to the alginic acid, the Psendomonas Pu binding sites must be proportionately much stronger.

Actinide binding to the polyprotic ligands is also localized at the molecular level. However, simulations of the environmental fate of actinide / organic ligands complexes also requires mathematically tractability. Actinide / organic ligands binding models can be built upon the affinity distributions for proton binding. While also not 'correct' with respect to molecular-level mechanisms, such continum level models are able to capture the macroscopic behavior over a 
range of system conditions. Table 1 presents postulated formation reactions and the derived stability constants for some of the organic ligands evaluated. Figure 7 compares 'domains' of Pu (IV) association with the bacterially-derived EPS in terms of $\log \mathrm{K}_{\mathrm{d}}$ values. Note that there are substantial and significant differences between the extracellular materials.

2.6 Role of bacterial EPS in Pu transport through saturated sand. Preliminary transport experiments of Pu with and without Pseudomonas fluoresense-derived EPS indicates that EPS acts to 'solubilize' Pu under advective flow conditions. In the absence of EPS, Pu sorbs with irreversible first-order kinetics to an immobile phase. In contrast, Pu / EPS complexes injected into the transport column sorb reversibly and with a retardation factor of $\sim 2$ relative to the transport of a conservative tracer (HTO). Such behavior is consistent with the observations of Wildung et al. (1987) on the solubilization potential of bacterial exudates. 
Table 1. Examples of postulated reactions and stability constants determined for environmental organic ligands.

\begin{tabular}{|c|c|c|}
\hline Ligand & Postulated reaction & $\log \mathbb{K}_{\mathrm{Hi}_{1}}(I=0)$ \\
\hline Citrate & $\mathrm{Pu}^{4+}+\mathrm{L}^{3+}=\mathrm{PuL}^{-}$ & 19.65 \\
\hline Galacturonic acid & $\mathrm{Pu}^{4+}+\mathrm{L}=\mathrm{PuL}^{3+}$ & 15.32 \\
\hline Alginic acid ${ }^{+}$ & $\begin{array}{l}\mathrm{Pu}^{4+}+2 \mathrm{HL}_{1}=\mathrm{Pu}\left(\mathrm{L}_{1}\right)_{2}{ }^{2+}+2 \mathrm{H}^{+} \\
\mathrm{Pu}^{4+}+2 \mathrm{HL}_{2}=\mathrm{Pu}\left(\mathrm{L}_{2}\right)_{2}{ }^{+2}+2 \mathrm{H}^{+}\end{array}$ & $\begin{array}{r}10.79 \\
9.54\end{array}$ \\
\hline Pseudomonas EPS & $\begin{array}{l}\mathrm{Pu}^{4+}+2 \mathrm{HL}_{1}=\mathrm{Pu}\left(\mathrm{L}_{1}\right)_{2}{ }^{2+}+2 \mathrm{H}^{+} \\
\mathrm{Pu}^{4+}+2 \mathrm{HL}_{2}=\mathrm{Pu}\left(\mathrm{L}_{2}\right)_{2}{ }^{2+}+2 \mathrm{H}^{+} \\
\left.\mathrm{Pu}^{4+}+2 \mathrm{HL}_{3}=\mathrm{Pu}\left(\mathrm{L}_{3}\right)_{2}\right)^{2+}+2 \mathrm{H}^{+}\end{array}$ & $\begin{array}{l}11.8 \\
15,2 \\
14.7\end{array}$ \\
\hline
\end{tabular}

$\overline{\mathrm{L}}_{1}, \mathrm{~L}_{2}$ and $\mathrm{L}_{3}$ represent the $\mathrm{pK}_{\mathrm{L}}=2,4$ and 6 ligands, respectively.

Publications in preparation or submitted at this point from this work:

Gillow, J.B., Honeyman, B.D., Francis, A.J. Anaerobic microbial transformation of plutonium in contaminated soil [to be submitted to Radiochim. Acta].

Harper-Arabie, R., B.D. Honeyman, P. Buckley. Binding of Pu to galacturonic acid and extracellular polymeric substances (EPS) from Shewanella pufrefaciens, Clostridium sp and S. putrefaciens. [Manuscript in preparation].

Kantar, C. and B.D. Honeyman. Binding of Pu to citric and alginic acids. [Manuscript in preparation].

Roberts, K., Santschi, P.H., Leppard, G.G., and West, M. 2004a. Composition of colloids from surface waters and ground waters in Colorado, Colloids and Surfaces, accepted.

Roberts, K, and Santschi, P.H. (2004). Inverse dependency of particle residence times in ponds to the concentration of phosphate, the limiting nutrient. $J$. Environ. Radioactivity, in press.

Roberts, K.A., Santschi, P.H., and Honeyman, B.D. 2004b. Exopolymeric Substances (EPS) acting as a colloid trap in the ternary system Plutonium - EPS - colloidal silica. [Manuscript in preparation.]

Santschi, P.H., and Roberts, K. (2002b). Actinide Migration from Contaminated Soil to Surface Water at the Rocky Flats Environmental Technology Site. J. Nuclear Sci. and TechnoL, Suppl. 3, 485-488.

Santschi, P.H., Roberts, K., and Guo, L. (2002a). The organie nature of colloidal actinides transported in surface water envitonments. Environ. Sci. Technol., 36, 3711-3719.

\section{Literature cited:}

Brown, M.L., Aldrich, HC., and Gauthier, J.J. (1995). Relationship between glycocalyx and povidone-iodine resistance in Pseudomonas aeruginosa (ATCC 27853) biofilms. Appl. Environ. Microbiol. 61(1): 187-193.

Fane, A.G., A.R. Awang, M. Bolko, R. Macoun, R. Schoefield, Y.R. Shen, and F. Zha (1992). Metal recovery from waste-water using membranes. Wat. Sci. Technol. 25:5-18.

Fukushima, M., Tatsumi, K., and Wada S. (1999). Evaluation of the intrinsic acid-dissociation constant of alginic acid by considering the electrostatic effect. Analytical Sciences 15, 1153 , 
Hanlon, G.W., Denyer, S.P., Olliff, C.J., and Itrahim, L.J. (2001). Reduction in exopolysaccharide viscosity as an aid to bacteriophage penetration through Pseudomonas aeruginosa biofilms. Appl. Environ. Microbiol, 67(6): 2746-2753.

Herbelin, A.L. and I.C. Westall (1996). FTTEQL: A Computer Program for Determination of Chemical Equilibritum constants from Experimental Data. Department of Chemistry, Oregon State Unjversity.

Korenevsky, A.A., E. Vinogradov, Y. Gorby, and T. Beveridge (2002). Characterization of the lipopolysaccharides and capsules of Shewanella spp. Appl. Environ. Microbiol. 68:46534657.

Lenhart, J.J., S.E. Cabaniss, P. MacCarthy and B.D. Honeyman (2000). Uranium (VI) complexation with citric, humic and fulvic acids. Radiochim. Acta., 88, 345-343.

Murphy, R.J. (2000). Thorium (TV) binding to organic and inorganic ligands: marine colloidal organic matter, marine polysaccharides and hematite. Ph.D. Dissertation, Environmental Science and Engineering, Colorado School of Mines, Golden, CO 80401.

Roberts, K, and Santschi, P.H. (2004). Inverse dependency of particle residence times in ponds to the concentration of phosphate, the limiting nutrient. J. Environ. Radioactivity, in press.

Roberts, K., Santsehi, P.H., Leppard, G.G., and West, M. (2004a). Composition of colloids from surface waters and ground waters in Colorado. Colloids and Surfaces, accepted.

Sabra, W. A.P. Zeng, and W.D. Deckwar (2001). Bacterial alginate: physiology, product quality, and process aspects. App. Micrabiol. Biotechnol. 56: 315-325.

Santschi, P.H., Roberts, K.A., and Honeyman, B.D. (2004). Interactions between actinides and environmental matrices, with special emphasis on Pu. 227th ACS National Meeting, Anaheim, CA, March 28-April 1.

Seltmann, G., and O. Holst (2001). The Bacterial Cell Wall. Springer Verlag, Berlin.

Stefansson, M. (1999). Assessment of alginic acid molecular weight and chemical composition through capillary electrophoresis. Anci. Chem. 71, 2373.

Westall, J. C. Jones, J. D., Turner, G. D., Zachara, J. M. (1995). Models for association of metal ions with heterogeneous environmental sorbents. 1. Complexation of Co(II) by leonardite hurnic acid as a function of $\mathrm{pH}$ and $\mathrm{NaClO}_{4}$ concentration. Environ. Sci. Techrol. 29, 951.

Wildung, R. E., T.R. Garland and J.E. Rogers (1983). Plutonium interactions with soil microbial metabolites: effect on plutonium sorption by soil. In Environmental Research on Actinide Elements. U.S. D.O.E. CONF-841142. 